\title{
"Who Will Judge the Many When the Game is Through?": Considering the Profound Differences Between Mental Health Courts and "Traditional" Involuntary Civil Commitment Courts
}

\author{
Michael L. Perlin, Esq. ${ }^{*}$
}

\section{INTRODUCTION}

For forty years, we have known that involuntary civil commitment hearings are -in most jurisdictions - "charades." When the Supreme Court noted, in Parham v. J.R., that the average length of a civil commitment hearing ranged from 3.8 to 9.2 minutes, ${ }^{2}$ the reaction of many

* Professor Emeritus of Law, Founding Director, International Mental Disability Law Reform Project, New York Law School; Co-founder, Mental Disability Law and Policy Associates; J.D. 1969, Columbia Law School; A.B. 1966, Rutgers University (michael.perlin@nyls.edu; mlperlin@mdlpa.net).

Portions of this paper were presented at the annual Therapeutic Jurisprudence Workshop at Osgoode Hall Law School, York University, Toronto, Ontario, Canada, October 15, 2016; at St. Joseph's Healthcare's Forensic Psychiatry Program, Hamilton, Ontario, Canada, December 14, 2016; at the Second International Conference on Non-Adversarial Justice: Integrating Theory and Practice as the keynote address, sponsored by the Australasian Institute of Judicial Administration, Sydney, New South Wales, Australia, April 8, 2017; at the annual meeting of the Forensic and Correctional Psychology Interest Section of the Wisconsin Psychological Association as part of a Critical Issues in Forensic Psychology workshop, Madison, Wisconsin, June 16, 2017, and at the biennial Congress of the International Academy of Law and Mental Health, Prague, Czech Republic, July 12, 2017.

My thanks to David Wexler, AnnMarie Dewhurst, Sandy Simpson, David Yamada, Heather Campbell, Gary Chaimowitz, and Dan Ambrosini for their helpful comments; to Sandy and to Voula Marinos for sharing their written work; and to Shelley Kierstead for convening and moderating the Osgoode Hall workshop. My special thanks, in memoriam, to the late Mike Jones for his help.

I also want to especially thank Naomi Weinstein for her extraordinarily helpful comments about current procedures in New York.

1. Michael L. Perlin, "Half-Wracked Prejudice Leaped Forth": Sanism, Pretextuality, and Why and How Mental Disability Law Developed as It Did, 10 J. CONTEMP. LEGAL Issues 3, 7 (1999).

2. Parham v. J.R., 442 U.S. 584, 609 n.17 (1979) (countenancing fewer procedural due process protections for juveniles facing civil commitment than in cases involving adults); see also Michael L. Perlin \& Alison J. Lynch, "She's Nobody's Child/The Law Can't Touch Her at All”: Seeking to Bring Dignity to Legal Proceedings Involving Juveniles, 56 FAM. CT. REV. 79, 88 (2018) (assessing the extent to which Parham has contributed to the shaming and humiliation of juveniles facing psychiatric institutionalization). 
who had done these cases was, "What? So long?!"3 The characterization of such hearings as being a "greased runway" to a state institution has never been disputed. ${ }^{4}$ Lawyers representing these individuals were bored or contemptuous; ${ }^{5}$ judges simply wanted to get cases moving; opposing counsel looked at their wrist watches to see when the cases would be done. ${ }^{6}$

This is not news to anyone who regularly did civil commitment hearings at any time since 1972 (the beginning of contemporary civil commitment law, coinciding with the Supreme Court's decision in

3. Before I became a professor, I spent thirteen years as a lawyer representing persons with mental disabilities, including three years in which my focus was primarily on such individuals charged with a crime. In this role, when I was Deputy Public Defender in Mercer County (Trenton), NJ, I represented several hundred individuals at the "maximum security hospital for the criminally insane" in habeas corpus hearings, the forerunner to civil commitment hearings, both in individual cases and in a class action. Dixon v. Cahill, No. L3097 7/y-71 P.W. (N.J. Super. Ct. Law Div. 1973) (final order reprinted in Michael L. Perlin \& Heather Ellis Cucolo, Mental Disability LaW § 19-8 (3d ed. 2017) and discussed in Michael L. Perlin, "For the Misdemeanor Outlaw": The Impact of the ADA on the Institutionalization of Criminal Defendants with Mental Disabilities, 52 ALA. L. REV. 193, 206$07 \mathrm{n} .94$ (2000)). For the next eight years, I was director of the NJ Division of Mental Health Advocacy. In that role, I supervised the representation of tens of thousands of individuals facing civil commitment at psychiatric facilities in New Jersey. See, e.g., Michael L. Perlin, "Infinity Goes Up on Trial": Sanism, Pretextuality, and the Representation of Defendants with Mental Disabilities, 16 QUT L. REV. 106 (2016); Michael L. Perlin, Mental Patient Advocacy by a Public Advocate, 54 PsYCHIATRIC Q. 169 (1982).

4. See, e.g., Leslie Scallet, The Realities of Mental Health Advocacy: State ex rel. Memmel v. Mundy, in Mental Health Advocacy: An Emerging Force in Consumers' Rights 79, 81 (Louis E. Kopolow \& Helene Bloom eds., 1977); Alan Schoenberger, "Voluntary" Commitment of Mentally Ill or Retarded Children: Child Abuse by the Supreme Court, 7 U. DAYTON L. REV. 1, 3031 (1981).

5. See Michael L. Perlin \& Alison J. Lynch, "Mr. Bad Example”: Why Lawyers Need to Embrace Therapeutic Jurisprudence to Root Out Sanism in the Representation of Persons with Mental Disabilities, 16 Wyo. L. REV. 299, 314 n.96 (2016) [hereinafter Perlin \& Lynch, Mr. Bad Example].

[The author] had occasion to speak to private counsel who had been assigned to represent a patient in a county in which the New Jersey Division of Mental Health Advocacy . . . did not represent patients. The assigned counsel asked [the author], "Why is the State wasting Id. money to pay me to do this bullshit?"

6. See PERLIN \& CUCOLO, supra note 3, § 2-6.3.3, at 2-74 n.458 ("Mental disability law generally regulates powerless individuals represented by passive counsel in invisible court proceedings conducted by bored or irritated judges."). Judges for such cases are frequently retired judges called back into service on "recall." The state of New Jersey's official policy requires judges seeking recall work to be willing to hear involuntary civil commitment cases. See N.J. STATE JUDICIARY, POLICY Governing ReCAll for Temporary SERVice Within the Judicial SyStem $§ 11$ (b) (July 19, 2001), https://www.judiciary.state.nj.us/attorneys/assets/directives/dir_12_01.pdf [https://perma.cc/ $8 \mathrm{R} 4 \mathrm{~N}-8 \mathrm{DTV}]$. "Priority for approving requests for recall service will be based on the following factors: ... b. Willingness to serve on a designated statewide priority for recall judges, e.g., civil commitment hearings, ISP, sexually violent predator cases." Id. 
Jackson $v$. Indiana ${ }^{7}$ ); I, and others, have written about this many times. ${ }^{8}$ Some sixteen years ago, I wrote the following (and to the best of my knowledge, it has never been contradicted): "[T] he overwhelming number of cases involving mental disability law issues are 'litigated' in pitch darkness. Involuntary civil commitment cases are routinely disposed of in minutes behind closed courtroom doors."

In this Article, I will contrast this shabby track record with the promises of those mental health courts (MHCs) that operate as problemsolving courts are supposed to operate, and I will discuss how these courts may provide due process and fair hearings. I will assess - via traditional "compare and contrast" means - these two ways of adjudicating cases involving persons with mental disabilities via the models of procedural justice and therapeutic jurisprudence, and I will end with some thoughts about other topics that must be considered in this context.

\section{Quality of COUNSEl AT TRADITIONAL Civil COMMitMENT HEARINGS}

If there has been any constant in modern mental disability law, "it is the near-universal reality that counsel assigned to represent individuals at involuntary civil commitment cases is likely to be ineffective." ${ }^{\prime 10} \mathrm{We}$ knew

7. 406 U.S. 715, 729-37 (1972) (applying procedural and substantive due process protections to the civil commitment process). I critiqued the Parham decision in Michael L. Perlin, An Invitation to the Dance: An Empirical Response to Chief Justice Warren Burger's Time-Consuming Procedural Minuets Theory, in Parham v. J.R., 9 Bull. AM. ACAD. PsychiatRY \& L. 149 (1981), reprinted in THERAPEUTIC JuRISPRUdENCE: THE LAW AS A ThERAPEUTIC AgENT 291 (David Wexler ed., 1990) [hereinafter Wexler, TheRAPEUTIC AGENT]; see also Perlin \& Lynch, supra note 2.

8. See, e.g., Michael L. Perlin \& John Douard, "Equality, I Spoke That Word/As If a Wedding Vow": Mental Disability Law and How We Treat Marginalized Persons, 53 N.Y.L. SCH. L. ReV. 9 (2008-2009); Perlin, supra note 1, at 6-9; Michael L. Perlin, "John Brown Went Off to War": Considering Veterans' Courts as Problem-Solving Courts, 37 Nova L. Rev. 445 (2013).

9. Michael L. Perlin, A Law of Healing, 68 U. CIN. L. REv. 407, 425 (2000). See, e.g., JAMES A. HOLSTEIN, COURT-ORDERED INSANITY: INTERPRETIVE PRACTICE AND INVOLUNTARY COMMITMENT, at xvi (1993); James A. Holstein, Court Ordered Incompetence: Conversational Organization in Involuntary Commitment Hearings, 35 SOC. PROBS. 459 (1988).

This is not to say that all states operate in the same way. In New York - not coincidentally, where there is a dedicated state-wide program to provide representation to the population in questionhearings are open to the public and take substantially longer. Personal Communication with Naomi Weinstein, Senior Staff Attorney, Mental Hygiene Legal Services, in N.Y.C., N.Y. (Oct. 22, 2016).

10. Michael L. Perlin, "I Might Need a Good Lawyer, Could Be Your Funeral, My Trial": Global Perspective on the Right to Counsel in Civil Commitment Cases, 28 WASH. U. J.L. \& POL'Y 241, 241 (2008) [hereinafter Perlin, Could Be Your Funeral]. On the passivity of counsel in such cases, see Michael L. Perlin, Fatal Assumption: A Critical Evaluation of the Role of Counsel in Mental Disability Cases, 16 LAW \& HuM. BEHAV. 39, 43 (1992). This, of course, presumes that counsel is available to represent these individuals. See, e.g., Alison J. Lynch \& Michael L. Perlin, "Life's Hurried Tangled Road": A Therapeutic Jurisprudence Analysis of Why Dedicated Counsel Must Be Assigned to Represent Persons with Mental Disabilities in Community Settings, 35 BEHAV. SCI. \& L. 353, 355-57 (2017). Professor Heather Campbell has reminded me that in Canada, such representation is not 
this as the modern era began. ${ }^{11}$ We knew it when some courts (the case of Lessard v. Schmidt ${ }^{12}$ is the perfect example) started taking more seriously some of the other substantive and procedural rights of persons who were the subjects of such hearings. ${ }^{13}$ We knew it when so few states chose to follow the examples of New York, New Jersey, and a handful of other jurisdictions ${ }^{14}$ that legislatively created regularized, dedicated, specialized legal services offices whose primary job was to provide representation at such hearings. ${ }^{15}$ We knew it when the first empirical research showed that most lawyers prepared much less for civil commitment cases than for other cases, many did not speak to clients before the hearing, and they "rarely

mandatory in all provinces. It is also not mandatory in all states in Australia. See Michael L. Perlin, Three Kinds of Therapeutic Jurisprudence (and One Kind of Not-TJ), INT'L SOC'Y FOR THERAPEUTIC JURIS. (Aug. 3, 2017), https://mainstreamtj.wordpress.com/2017/08/03/three-kinds-of-therapeuticjurisprudence-and-one-kind-of-not-tj/ [https://perma.cc/EQ3Y-2CM8] (discussing ELEANORE Fritze, The Jack Brockhoff Found., Shining A Light Behind Closed Doors 28-31 (Dec. 2015), https://www.churchilltrust.com.au/media/fellows/Fritze_E_Shining_a_light_behind_closed_ doors.pdf [https://perma.cc/HLY9-N4MR]).

Also, in many U.S. jurisdictions, lawyers' caseloads are far too heavy to allow individualized representation. Years ago, a study in Chicago found that a single public defender was assigned to handle all civil commitment cases in the city of Chicago - a prohibitive case load of forty to sixty cases per week and 2,000-3,000 cases per year. See Elliott Andalman \& David L. Chambers, Effective Counsel for Persons Facing Civil Commitment: A Survey, a Polemic, and a Proposal, 45 Miss. L.J. 43,61 (1974). When that study was replicated twenty years later, it found a caseload of 2,000 per year in another county (presumably in Florida). Sumner J. Sydeman et al., Procedural Justice in the Context of Civil Commitment: A Critique of Tyler's Analysis, 3 Psychol. PUB. POL'y \& L. 207, 216 n.49 (1997). The American Bar Association takes the position that the maximum caseload should be 200, one-tenth of this number. See Megan Annitto, Juvenile Justice on Appeal, 66 U. MIAMI L. REV. 671, 674 n.9 (2012) (citing and quoting AM. BAR Ass'N, STANDING COMM. ON LEGAL AID \& INDIGENT Defendants, Ten Principles of a Public Defense Delivery System 1, 5 n.19 (2002)).

Beyond the scope of this paper is a consideration of an important collateral issue: that there are often not the community support services in place (e.g., housing and less restrictive alternative treatment facilities) that should be available to all who are subject to the involuntary civil commitment process. See Naomi M. Weinstein \& Michael L. Perlin, "Who's Pretending to Care for Him?” How the Endless Jail-to-Hospital-to-Street-Repeat Cycle Deprives Persons with Mental Disabilities the Right to Continuity of Care, WAKE FOREST J. L. \& POL'Y (forthcoming 2018) (manuscript at 13-14) (on file with authors) [hereinafter Weinstein \& Perlin, Who's Pretending to Care for Him?].

11. See, e.g., Andalman \& Chambers, supra note 10, at 72 (speculating that counsel was so inadequate in the sample study that patients' chances for hospital release were enhanced if no lawyer was present); George E. Dix, Acute Psychiatric Hospitalization of the Mentally Ill in the Metropolis: An Empirical Study, 1968 WASH. U. L.Q. 485, 540 (1968) (noting that only two of 1,700 contested cases resulted in patient release).

12. 349 F. Supp. 1078, 1087 (E.D. Wis. 1972) (holding that a statute that fails to provide a person alleged to be mentally ill with adequate procedural safeguards is unconstitutional).

13. Scallet, supra note 4, at 81.

14. See, e.g., In re Judicial Commitment of C.P.K., 516 So. 2d 1323, 1325 (La. Ct. App. 1987) (reversing commitment order where trial court failed to comply with statute expressing explicit preference for representation by state Mental Health Advocacy Service and rejecting as "untenable" argument that trial court should be excused "since it did not know ... whether the Service really existed”); MASS. GEN. LAwS ch. 123, § 23 (2016); OHio Rev. Code ANN. § 5123.60 (West 2017).

15. See, e.g., N.Y. Mental Hyg. LAW $\S \$ 47.01-47.03$ (McKinney 2017); N.J. STAT. ANN. 52:27E-55 (West 2017). 
took an adversary role to obtain release of their clients whom psychiatrists had recommended for commitment." 16 And importantly, we knew it when it became clear that only in those jurisdictions that had dedicated counsel programs was there any coherent body of reported civil commitment case law. ${ }^{17}$ There are dedicated offices that provide top-flight legal representation to persons with mental disabilities in civil commitment hearings, but these offices represent a small percentage of those subject to commitment. ${ }^{18}$

Sadly, "the quality of counsel assigned to represent individuals who face involuntary civil commitment to psychiatric hospitals is, in most United States jurisdictions, mediocre or worse." 19 The data tells us that, in many jurisdictions, counsel is "woefully inadequate-disinterested, uninformed, roleless, and often hostile." 20 Startlingly, "this reality goes almost unmentioned in the legal literature." ${ }^{21}$

16. Virginia Aldigé Hiday, Are Lawyers Enemies of Psychiatrists? A Survey of Civil Commitment Counsel and Judges, 140 AM. J. PsychiATRY 323, 326 (1983).

17. See, e.g., Michael L. Perlin, "You Have Discussed Lepers and Crooks": Sanism in Clinical Teaching, 9 CLINICAL L. REV. 683, 708-09 (2003).

A contrast between the development of case law in Virginia and Minnesota is especially instructive. Notwithstanding the fact that Virginia's population is approximately $15 \%$ greater than Minnesota's, Virginia had only two published litigated civil cases on questions of mental hospitalization during the decade from 1976 to 1986, while Minnesota had at least 101 such cases in the same period. Significantly, Minnesota has a tradition of providing vigorous counsel to persons with mental disabilities, while Virginia does not.

Id.

18. See PerLin \& CuCOLO, supra note 3, §§ 6-4.2 to 6-4.3.

19. Perlin, Could Be Your Funeral, supra note 10, at 243. In a white paper that I prepared for the American University School of Public Affairs' Justice Programs Office on the question of the quality of representation of criminal defendants with mental disabilities, I focused on several issues that required attention in determining adequacy of counsel in cases involving this population: the "fear of faking," the likelihood of undiagnosed or misdiagnosed disabilities, and the impact of prescribed medications on mental functioning. Michael L. Perlin, Am. Univ., Justice Programs Office, REPRESENTING CLIENTS WITH MENTAL HEALTH AND/OR COGNITIVE IMPAIRMENTS IN TREATMENT COURTS 3 (2016), http://www.american.edu/spa/jpo/initiatives/drug-court/upload/Perlin-MentalImpairments-7-8-16.pdf [https://perma.cc/DM26-89EL]. Certainly, the vast majority of lawyers appointed episodically or randomly to represent persons with mental disabilities at civil commitment hearings invariably miss these issues.

20. Michael L. Perlin, "And My Best Friend, My Doctor/Won't Even Say What It Is I've Got": The Role and Significance of Counsel in Right to Refuse Treatment Cases, 42 SAN DIEGO L. REV. 735, 738 (2005). See also_Henry A. Dlugacz \& Christopher Wimmer, The Ethics of Representing Clients with Limited Competency in Guardianship Proceedings, 4 ST. LoUIS U. J. HeAlth L. \& POL'Y 331, 353-54 (2011).

There are also institutional pressures: The attorney who depends on the goodwill of others in the system (e.g., judges, state attorneys, or prosecutors) may pull his punches, even unwittingly, in order to retain credibility for future interactions (which he would put to use Id.

for his future clients). Judges want cases resolved.

21. Perlin, Could Be Your Funeral, supra note 10, at 243. In 2008, the author noted that a Westlaw search of "(adequacy effectiveness) +3 counsel /s 'civil commitment"' revealed no articles 
Counsel on the "other side of the table" does not have a sterling track record either. In his concurrence in O'Connor v. Donaldson, ${ }^{22}$ then-Chief Justice Warren Burger noted that, at retrial, "I would hope these sensitive and important issues would have the benefit of more effective presentation and articulation on behalf of petitioner [defendant/state psychiatrist]. ${ }^{23} \mathrm{In}$ this context, Professor David Wexler has noted that "it does not appear that the state's public protection and therapeutic interests are being advanced under a scheme defendable as a coherent policy of appropriate advocacy in mental health cases." ${ }^{24}$ Importantly, in the same articlewritten nearly thirty-five years ago-Wexler noted that "discussions of advocacy in mental health law have rarely touched on the appropriate role of attorneys representing commitment petitioners or state hospitals." ${ }^{25}$ As Professor Wenona Whitfield has observed, "state's attorneys ... have little incentive or interest in making this area of the law their specialty." 26

Further, judges "generally have little judicial experience and little incentive to develop expertise in this area." 27 Their lack of interest "conveys the message that patients' rights . . . are not important." ${ }^{28}$ Simply put, judges subordinate mental disability law issues (a reflection and

other than those that he had written. Id. at 243 n.14. When the same search was repeated last year, in addition to those articles (and ones citing a different article by the author, see Michael L. Perlin \& Deborah A. Dorfman, Is It More than "Dodging Lions and Wastin' Time"? Adequacy of Counsel, Questions of Competence, and the Judicial Process in Individual Right to Refuse Treatment Cases, 2 PSYCHOL. PUB. POL'Y \& L. 114 (1996)), the search revealed only two others: Grant H. Morris, "Let's Do the Time Warp Again": Assessing the Competence of Counsel in Mental Health Conservatorship Proceedings, 46 SAn Diego L. Rev. 283 (2009) and Joseph Frueh, The Anders Brief in Appeals from Civil Commitment, 118 YALE L.J. 272 (2008) (search performed Aug. 29, 2016).

22. 422 U.S. 563 (1975).

23. Id. at 578 n.1.

24. David B. Wexler, Inappropriate Patient Confinement and Appropriate State Advocacy, 45 LAW \& CONTEMP. PROBS. 193, 202 (1982).

25. Id. at 193. Wexler further suggests, in this context, that state counsel often engages in pretextual advocacy by counsel automatically assuming an adversarial role at release hearings and advocating needless or inappropriate confinement. Id. at 198-200; see also Deborah A. Dorfman, Through a Therapeutic Jurisprudence Filter: Fear and Pretextuality in Mental Disability Law, 10 N.Y.L. SCH. J. HUM. RTS. 805, 814 (1993) (discussing pretextual advocacy by state counsel in this context as well).

26. Wenona Whitfield, Capacity, Competency, and Courts: The Illinois Experience, 14 WASH. U. J.L. \& POL'Y 385, 405 (2004).

27. Id. at 404. My personal experience decades ago was that judges often cut off my attempts at cross-examination, both on voir dire of experts and on the experts' opinions of cases. An attorney whom I know well, who has requested anonymity, and who does similar cases now reported: "[There are] judges who would give more time to petitioner's side and less time to us (to the point where I would start timing how long petitioner's attorney got to ask questions so that I could say my cross should be allowed to be at least that long)." Personal Communication to Author (Oct. 23, 2016).

28. Michael L. Perlin, Keri K. Gould \& Deborah A. Dorfman, Therapeutic Jurisprudence and the Civil Rights of Institutionalized Mentally Disabled Persons: Hopeless Oxymoron or Path to Redemption? 1 PsYchOL. PUB. POL'Y \& L. 80, 116 (1995). 
extension of their subordination of mentally disabled persons). ${ }^{29}$ This subordination translates into a failure to inform patients of their rights at such hearings. A study by Charles D. Parry and Eric Turkheimer revealed that, at the patient's initial hearing, fewer than one-third of judges told patients of their right to counsel, fewer than one-fourth told patients of their right to voluntary status, and about two-fifths told patients of their right to appeal; by the second review hearing after six to twelve months in the hospital, less than five percent of judges mentioned the right to counsel and less than eight percent mentioned voluntary admissions, while fifteen percent referred to the right to appeal. ${ }^{30}$ There is no contesting Professor Sarah Gordon's conclusion that "civil commitment proceedings tend to be short and perfunctory." 31

Judges typically defer to the judgments of state experts ${ }^{32}$ without any acknowledgement of the robust, valid, and reliable evidence that tells us

29. Michael L. Perlin, Therapeutic Jurisprudence: Understanding the Sanist and Pretextual Bases of Mental Disability Law, 20 New ENG. J. ON CRIM. \& Civ. CONFINEMENT 369, 377 (1994).

30. Charles D. Parry \& Eric Turkheimer, Length of Hospitalization and Outcome of Commitment and Recommitment Hearings, 43 HOSP. \& COMMUNITY PSYCHIATRY 65, 66 (1992). Remarkably, this article has not subsequently been cited in the legal literature in nearly twenty years. See Stephanie Proctor Miller, Keeping the Promise: The ADA and Employment Discrimination on the Basis of Psychiatric Disability, 85 CAL. L. REv. 701, 703 n.14 (1997); Sydeman et al., supra note 10, at 208 n.7.

31. Sara Gordon, The Danger Zone: How the Dangerousness Standard in Civil Commitment Proceedings Harms People with Serious Mental Illness, 66 CASE W. RES. L. REV. 657, 678 (2016). On how civil commitment threatens a person's liberty and dignity with "equally drastic consequences as those associated with criminal prosecutions," see People v. Hurtado, 124 Cal. Rptr. 2d 186, 197 (Cal. 2002), cert. denied, 583 U.S. 963 (2003), as discussed in Meehan Rasch, California's Dueling Harmless Error Standards: Approaches to Federal Constitutional Error in Civil Proceedings and Establishing the Proper Test for Dependency, 35 W. ST. U. L. REV. 433, 448 (2008).

32. See, e.g., Morris, supra note 21, at 314-15 ("[D] espite the fallibility of psychiatric testimony, judges and juries, serving as fact finders in civil commitment and conservatorship proceedings, typically defer to psychiatric judgments that the person has a mental disorder and that the mental disorder meets the statutory standard for commitment or a conservatorship."). The only two studies of judges' views on this question found that judges consider expert testimony to be the most important factor in their commitment decisions. See Stephanie Evans \& Karen Salekin, Involuntary Civil Commitment: Communicating with the Court Regarding "Danger to Other," 38 LAW \& Hum. BeHaV. 325,326 (2014).

Most courts that have considered the question have agreed that constitutional due process in a civil commitment hearing "includes the right to an independent psychiatric examination." In re Gannon, 301 A.2d 493, 494 (N.J. Super. Ct. 1973). See Scott F. Uhler, The Constitutional Right of the Indigent Facing Involuntary Civil Commitment to an Independent Psychiatric Examination, 20 AKron L. ReV. 71, 72 (1986). See generally Perlin \& CuCOlo, supra note 3, § 6-9, at 6-104 to 6106.1. But see Goetz v. Crosson, 967 F.2d 29, 36-37 (2d Cir. 1992) (affirming a trial court opinion holding that the Due Process Clause does not confer an absolute right to state-provided psychiatric assistance at involuntary civil commitment hearings and mandating such a right only when the hearing judge determines that expert testimony "is necessary to a reliable assessment of a patient").

There are no statistics available, but the forty years I have spent litigating these cases and observing them in multiple jurisdictions has made it clear to me that in most venues, such expert witnesses are virtually never engaged. But see Stefan Sjöström, Maritha Jacobsson \& Anna Hollander, Collegiality, 
how imprecise clinical predictions of dangerousness often are. ${ }^{33}$ By doing so, they allow "psychiatrist experts [to] actually become the decisionmakers in the civil commitment process," 34 serving as "rubber stamps of psychiatrists' testimony." 35 As Professor Gordon points out, "civil commitment proceedings may not be given priority by judges with busy caseloads, who may therefore lack an incentive to carefully scrutinize psychiatrists' recommendations."36

What I have reported on here is all infinitely depressing, but it is not new; nor is the lack of interest in the subject matter new. The Scallet article - the first using the phrase "greased runway" in this context $\mathrm{t}^{37}$-is nearly forty years old. Important pieces, such as Wexler's, ${ }^{38}$ on the role of the state in this context have been cited only a handful of times. There has been no discernable impact of studies such as the one done by Parry and Turkheimer. ${ }^{39}$ In short, in the nearly forty years since I started writing about this topic (a topic to which I continue to return) ${ }^{40}$ very little has changed in the context of involuntary civil commitment trials. They remain, in the words of the eminent forensic psychiatrist Paul Appelbaum,

Therapy and Mediation - The Contribution of Experts in Swedish Mental Health Law, 6 LAws, no. 1, 2017, at 1, http://www.mdpi.com/2075-471X/6/1/2/htm [https://perma.cc/9AQN-4XA9] (criticizing lack of independence on part of court-appointed psychiatrists in Swedish civil commitment cases).

33. See, e.g., Heller v. Doe, 509 U.S. 312, 323-24 (1993). There are "difficulties inherent in diagnosis of mental illness. It is thus no surprise that many psychiatric predictions of future violent behavior by the mentally ill are inaccurate." Id. This has been known for decades. See, e.g., JOHN Monahan, Predicting Violent Behavior: An Assessment of Clinical Techniques 92 (1981) (two out of three predictions of dangerousness by psychiatrists and psychologists are inaccurate); Joseph J. Cocozza \& Henry J. Steadman, The Failure of Psychiatric Predictions of Dangerousness: Clear and Convincing Evidence, 29 RUTGERS L. REV. 1084, 1096-97 (1976). Clinicians have been found to be no better than chance when it came to predicting violence among female patients. See John Monahan, Nat'L Inst. of Justice, Mental Illness AND Violent Crime 1-2 (Oct. 1996).

34. William M. Brooks, The Tail Still Wags the Dog: The Pervasive and Inappropriate Influence by the Psychiatric Profession on the Civil Commitment Process, 86 N.D. L. REv. 259, 285 (2010); see also Robert A. Brooks, Psychiatrists' Opinions About Involuntary Civil Commitment: Results of a National Survey, 35 J. AM. ACAD. PsyCHIATRY L. 219, 219 (2007) [hereinafter Brooks, Psychiatrists' Opinions].

35. Brooks, Psychiatrists' Opinions, supra note 34, at 220.

36. Gordon, supra note 31, at 678 (citing Paul S. Appelbaum, Civil Commitment from a Systems Perspective, 16 LAW \& HUM. BEHAV. 61, 66-67 (1992)).

37. Scallet, supra note 4.

38. Wexler, supra note 24.

39. Parry \& Turkheimer, supra note 30.

40. Compare Michael L. Perlin \& Robert L. Sadoff, Ethical Issues in the Representation of Individuals in the Commitment Process, 45 LAW \& CONTEMP. PROBS. 161 (1982), with Michael L. Perlin \& Naomi M. Weinstein, "Said I, 'But You Have No Choice'”: Why a Lawyer Must Ethically Honor a Client's Decision About Mental Health Treatment Even if It Is Not What S/he Would Have Chosen, 15 CARDOZO PUB. L. POL'Y \& ETHICS J. 73 (2016-2017). I first discussed these issues in Michael L. Perlin, Representing Individuals in the Commitment and Guardianship Process, in 1 Legal Rights of Mentally Disabled Persons 497 (Paul Friedman ed., 1979). 
the "disfavored stepchild in the large family of concerns that must be addressed by the justice system." ${ }^{41}$

\section{The Promise of Mental Health COURTS}

However, consider next the parallel universe of MHCs. ${ }^{42}$ There is no question that one of the most important developments in the past two decades in the way that criminal defendants with mental disabilities are treated in the criminal process has been the creation and expansion of MHCs, one kind of "problem-solving court." ${ }^{33}$ The creation of these courts is particularly critical as we-tardily-begin to come to grips with the ways that persons with mental disabilities are disproportionately arrested for "nuisance crimes" and the significance of MHCs grows. ${ }^{44}$ There is a wide range of dispositional alternatives available to judges in these cases ${ }^{45}$ and an even wider range of judicial attitudes. ${ }^{46}$ And the entire concept of MHCs is certainly not without controversy. ${ }^{47}$

There is no question, however, that MHCs offer a new approachperhaps a radically new approach — to the problems at hand. ${ }^{48}$ They

41. Appelbaum, supra note 36, at 66 (as quoted in Gordon, supra note 31, at 678).

42. See generally Michael L. Perlin, "The Judge, He Cast His Robe Aside": Mental Health Courts, Dignity and Due Process, 3 Mental Health L. \& Pol'y J. 1 (2013) [hereinafter Perlin, Cast His Robe]; Michael L. Perlin, "There Are No Trials Inside the Gates of Eden": Mental Health Courts, the Convention on the Rights of Persons with Disabilities, Dignity, and the Promise of Therapeutic Jurisprudence, in COERCIVE CARE: LAW AND POLICY 193 (Bernadette McSherry \& Ian Freckelton, eds., 2013) [hereinafter Perlin, Gates of Eden].

43. See, e.g., Greg Berman \& John Feinblatt, Problem-Solving Courts: A Brief Primer, 23 LAW \& POL'Y, 125, 127 (2001); Greg Berman \& Aubrey Fox, The Future of Problem-Solving Justice: An International Perspective, 10 U. MD. L.J. RACE RELIG. GENDER \& CLASS 1, 3 (2010); see also Ursula Castellano, The Politics of Benchcraft: The Role of Judges in Mental Health Courts, 42 LAW \& SoC. INQUIRY 398, 398 (2017).

44. See, e.g., Michael L. Perlin \& Alison J. Lynch, "Had to Be Held Down by Big Police”: A Therapeutic Jurisprudence Perspective on Interactions Between Police and Persons with Mental Disabilities, 43 Fordham URB. L.J. 685, 687-89 (2016) [hereinafter Perlin \& Lynch, Big Police]; Lynch \& Perlin, supra note 10; Michael L. Perlin \& Alison J. Lynch, "To Wander Off in Shame": Deconstructing the Shaming and Shameful Arrest Policies of Urban Police Departments in Their Treatment of Persons with Mental Disabilities, in Power, Humiliation and Violence (Daniel Rothbart ed., forthcoming 2017) [hereinafter Perlin \& Lynch, To Wander Off in Shame]. On the lack of continuity of care in such cases, see Weinstein \& Perlin, Who's Pretending to Care for Him? supra note 10 .

45. See, e.g., Henry J. Steadman et al., From Referral to Disposition: Case Processing in Seven Mental Health Courts, 23 BeHAV. SCI. LAW 215, 220-21 (2005).

46. See, e.g., Michael S. King, Should Problem-Solving Courts Be Solution-Focused Courts?, 80 REV. JUR. U.P.R. 1005, 1008 (2011).

47. See, e.g., Tammy Seltzer, A Misguided Attempt to Address the Criminal Justice System's Unfair Treatment of People with Mental Illness, 11 PsYCHOL. PUB. POL'Y \& L. 570, 576 (2005). For a recent - and sobering - empirical critique of such courts in one jurisdiction, see Johnston \& Flynn, infra note 84 .

48. Some jurisdictions are beginning to seek out other alternative and complementary solutions to these issues. For recently-passed New York City local laws addressing the issue of mental health in 
become even more significant because of their articulated focus on dignity, ${ }^{49}$ as well as their embrace of therapeutic jurisprudence, their focus on procedural justice, and their use of the principles of restorative justice. ${ }^{50}$ It is time to restructure the dialogue about MHCs and to begin to take seriously the potential ameliorative impact of such courts on the ultimate disposition of all cases involving criminal defendants with mental disabilities. $^{51}$

It needs to be stressed that MHCs are set up differently in different jurisdictions. There are now over 375 such courts in operation in the

the criminal system, see, e.g., N.Y.C., N.Y., Law Number 2016/124 (Oct. 18 2016), http://legistar.council.nyc.gov/LegislationDetail.aspx?ID=2735148\&GUID=44E35DA3-1843-445695B6-511D0FF7EFB7 [https://perma.cc/8B2W-ZBMJ]; N.Y.C., N.Y., Law Number 2016/123 (Oct. 18 2016), http://legistar.council.nyc.gov/LegislationDetail.aspx?ID=2683868\&GUID=50FF659A5D11-42BC-A364-C15155C237CC\&Options $=\&$ Search $=\quad[$ https://perma.cc/N89H-VMNX]. See generally Perlin \& Lynch, Big Police, supra note 44; Perlin \& Weinstein, supra note 40. For other new and innovative options being pursued in New York City, see THE CiTY OF N.Y., THRIVE NYC: A ROADMAP FOR MENTAL HEALTH FOR ALL (Oct. 2016), https://thrivenyc.cityofnewyork.us/wpcontent/uploads/2017/02/ThriveNYC.pdf [https://perma.cc/E6HM-35PM].

49. See Ginger Lerner-Wren, Mental Health Courts: Serving Justice and Promoting Recovery, 19 ANNALS HEALTH L. 577, 593 (2010) (explaining dignity in the context of MHCs).

50. See Michael L. Perlin, A Prescription fOr Dignity: Rethinking Criminal Justice and Mental Disability Law 88-96 (2013) [hereinafter Perlin, A Prescription For Dignity] (discussing restorative justice); Jessica Burns, A Restorative Justice Model for Mental Health Courts, 23 S. CAL. REV. L. \& Soc. Just. 427, 447-54 (2014); Thomas L. Hafemeister, Sharon G. Garner \& Veronica E. Bath, Forging Links and Renewing Ties: Applying the Principles of Restorative and Procedural Justice to Better Respond to Criminal Offenders with a Mental Disorder, 60 BuFF. L. REV. 147, 201-02 (2012) (on procedural justice); Henry J. Steadman et al., Mental Health Courts: Their Promise and Unanswered Questions, 52 PSYCHIATRIC SERVICES 457, 457-58 (2001) (discussing therapeutic jurisprudence in this context). On the relationship between these three approaches, see Perlin, A PRESCRIPTION FOR Dignity, supra note 50, at 96-98; Michael L. Perlin, Considering the "Alternative Jurisprudences" as a Tool of Social Change to Reduce Humiliation and Uphold Dignity (2012) (unpublished manuscript), http://www.humiliationstudies.org/documents/PerlinNY12AlternativeJurisprudences.pdf [https://perma.cc/7NZX-TKTC] (paper presented to the 20th Annual Conference of the Human Dignity and Humiliation Studies Network).

51. On the utility of MHCs in other jurisdictions, see generally Penelope Weller, Taking a Reflexive Turn: Non-Adversarial Justice and Mental Health Review Tribunals, 37 MONASH U. L. REV. 82 (2011) (Austl.); Katey Thom, New Zealand Mental Health Review Tribunal Characteristics and Outcomes 1993-2011, 22 AUSTRALASIAN PSYCHIATRY 341 (2014) (N.Z.). On why the proposed Disability Rights Tribunal for Asia and the Pacific should, in part, operate under these principles, see generally Michael L. Perlin, Promoting Social Change in Asia and the Pacific: The Need for a Disability Rights Tribunal to Give Life to the UN Convention on the Rights of Persons with Disabilities, 44 GeO. WASH. InT'L L. REV. 1 (2012); Michael L. Perlin \& Mehgan Gallagher, Why a Disability Rights Tribunal Must Be Premised on Therapeutic Jurisprudence Principles, 10 PsYCHOL. INJ. \& L. 244 (2017); Yoshikazu Ikehara, Presentation at the International Conference on the Disability Rights Tribunal in Asia \& the Pacific, What Is the DRTAP Project and Its Future?, slides 11-17 (Oct. 22, 2010), http://slideplayer.com/slide/6189878/ [https://perma.cc/8QTF-R9S3] (discussing all statutes). 
United States, ${ }^{52}$ some dealing solely with misdemeanors,${ }^{53}$ some dealing solely with nonviolent offenders ${ }^{54}$ and some dealing with no such restrictions. $^{55}$

Although there is no single prototype, virtually all MHCs include a special docket handled by a particular judge, with the primary goal of diverting defendants from the criminal justice system and into treatment. ${ }^{56}$ MHCs are premised on team approaches; ${ }^{57}$ representatives from justice and treatment agencies assist the judge in screening offenders to determine whether they would present a risk of violence if released to the community, devising appropriate treatment plans, and supervising and monitoring the individual's performance in treatment. ${ }^{58}$ The MHC judge functions as part

52. Drug Treatment Courts by State, NAT'L Drug CT. Resource CTR., http://www.ndcrc.org/content/how-many-problem-solving-courts-are-there [https://perma.cc/FP6ZRBMK] (as cited in Donald M. Linhorst \& P. Ann Dirks-Linhorst, Mental Health Courts: Development, Outcomes, and Future Challenges, JudGES' J., Spring 2015, at 22, 22).

53. See, e.g., Ursula Castellano, Courting Compliance: Case Managers as "Double Agents" in the Mental Health Court, 36 LAW \& SOC. INQUIRY 484, 490 (2011).

54. See, e.g., Julie Grachek, The Insanity Defense in the Twenty-First Century: How Recent United States Supreme Court Case Law Can Improve the System, 81 IND. L.J. 1479, 1495 (2006).

55. See, e.g., E. Leah Johnston, Theorizing Mental Health Courts, 89 WASH. U. L. REV. 519, 521 (2012). See generally Carol Fisler, Building Trust and Managing Risk: A Look at a Felony Mental Health Court, 11 Psychol. PUB. POL'Y \& L. 587 (2005) (on the expansion of these courts to include felony prosecutions).

56. Roger A. Boothroyd et al., The Broward Mental Health Court: Process, Outcomes, and Service Utilization, 26 INT'L J.L. \& PSYCHIATRY 55, 55 (2003). At least one evaluation of such courts has concluded "most ... defendants have been 'nuisance' offenders who have a high incidence of drug co-morbidity, treatment plan noncompliance, and recidivism .... Their high recidivism rate and the problem of severe jail overcrowding made the mental health court experiment especially attractive to some county policy makers." Gerald Nora, Prosecutor As "Nurse Ratched"? Misusing Criminal Justice as Alternative Medicine, CRIM. JUST., Fall 2007, at 18, 22. Individuals before MHCs are also often in need of legal services dealing with matters such as housing or domestic issues. Beyond the scope of this paper is an inquiry into how the problem-solving courts that have been created to deal with these problems could best be integrated with MHCs. See Perlin \& Gallagher, supra note 51 (relying upon, inter alia, Raymond H. Brescia, Beyond Balls and Strikes: Towards a Problem-Solving Ethic in Foreclosure Proceedings, 59 CASE W. RES. L. REV. 305 (2009)); Raymond L. Pianka, Community Control Supervision of Building Code Offenders in Cleveland's Housing Court: Making the Most of Ohio's Direct Sentencing for Misdemeanors, 46 U. MEM. L. Rev. 903 (2016)).

57. See, e.g., Arthur J. Lurigio \& Jessica Snowden, Putting Therapeutic Jurisprudence into Practice: The Growth, Operations, and Effectiveness of Mental Health Court, 30 JUST. SYS. J. 196, 210-11 (2009); Marlee E. Moore \& Virginia A. Hiday, Mental Health Court Outcomes: A Comparison of Re-Arrest and Re-Arrest Severity Between Mental Health Court and Traditional Court Participants, 30 LAW \& HUM. BEHAV. 659, 660 (2006). For a discussion of variances in team approaches, see Sheryl Kubiak, Liz Tillander \& Bradley Ray, Assessing the Role of Legal Actors Across Eight Mental Health Courts, 17 Mich. ST. U. J. MED. \& L. 301, 304 (2013). For an article urging that MHCs be employed at the pre-adjudication level of the criminal court process, see generally Caitlin T. Harrington, Breaking the Cycle and Stepping out of the "Revolving Door": Why the Pre-Adjudication Model Is the Way Forward for Illinois Mental Health Courts, 2013 U. ILL. L. REV. 319 (2013).

58. Bruce J. Winick, Outpatient Commitment: A Therapeutic Jurisprudence Analysis, 9 PSYCHOL. PUB. POL'Y \& L. 107, 125-26 (2003). On the role of jail as a potential sanction in the cases 
of a mental health team that assesses the individual's treatment needs ${ }^{59}$ and decides whether he or she can be safely released to the community. ${ }^{60}$ The team formulates a treatment plan, and a court-employed case manager and court monitor track the individual's participation in the treatment program and submit periodic reports to the judge concerning his or her progress. Participants are required to report to the court periodically so the judge can monitor treatment compliance, and additional status review hearings are held on an as-needed basis. ${ }^{61}$

To serve effectively in this sort of court setting and to best achieve the objectives of these courts, ${ }^{62}$ the judge needs to develop enhanced interpersonal skills and awareness of a variety of psychological techniques to persuade the individual to accept treatment and motivate him or her to participate effectively in it. ${ }^{63}$ The judge must be able to build trust and manage risk. ${ }^{64}$

of non-compliant defendants, see Allison Redlich et al., Patterns and Practice in Mental Health Courts: A National Survey, 30 LAW \& HUM. BeHAV. 347, 355-56 (2006).

59. See Shauhin Talesh, Mental Health Court Judges as Dynamic Risk Managers: A New Conceptualization of the Role of Judges, 57 DEPAUL L. REV. 93, 96 (2007).

$[\mathrm{W}]$ ith the assistance of team members - including the public defender, prosecutor, and behavioral and mental health specialists - the judge performs the following three tasks: (1) he conducts a risk assessment in which he evaluates the defendant's potential to harm himself and the public; (2) he evaluates and implements a treatment plan designed to manage and reallocate the defendant's risk; and (3) he monitors the risk over a period of time, often requiring frequent return visits by the defendant.

Id.

60. On the often-conflicting roles of case managers in MHCs, see Castellano, supra note 53, at 490-91. On how caseworkers, in other contexts, transform "traditional courtroom justice," see Ursula Castellano, Outsourcing Justice: The Role of NonProfit Caseworkers in PRETRIAL RELEASE PROGRAMS 9 (2011).

61. Susan Stefan \& Bruce J. Winick, A Dialogue on Mental Health Courts, 11 Psychol. PuB. POL'Y \& L. 507, 520-21 (2005). For a recent article articulating strategies to optimize criminal justicetreatment collaborations, see J. Steven Lamberti, Preventing Criminal Recidivism Through Mental Health and Criminal Justice Collaboration, 67 PSYCHIATRIC SERvices 1206 (2016). On how the adoption of a consumer-participation model in MHCs can improve mental health court participants' capacity for voluntary participation, see McDaniel M. Kelly, Rehabilitation Through Empowerment: Adopting the Consumer-Participation Model for Treatment Planning in Mental Health Courts, 66 CASE W. RES. L. REV. 581, 584 (2015).

62. Castellano, supra note 43 , at 400.

63. Winick, supra note 58, at 126 (citing Carrie Petrucci, Respect as a Component in the JudgeDefendant Interaction in a Specialized Domestic Violence Court that Utilizes Therapeutic Jurisprudence, 38 CRIM. L. BULL. 263 (2002)). On the "collateral institutional authority of the judge" in MHCs, see Eric J. Miller, The Therapeutic Effects of Managerial Reentry Courts, 30 FED. SENT'G REP. 127, 128 (2008). On the way that judgmental descriptive language can adversely affect the work of such courts in civil cases, see generally Ian Freckelton, Distractors and Distressors in Involuntary Status Decision-Making, 12 PSYCHIATRY PSYCHOL. \& L. 88 (2005).

64. Fisler, supra note 55, at 587. On the significance of trust in the context of youth and family courts, see generally Karni Perlman, It Takes Two for TJ: Correlation Between Bench and Bar Attitudes Towards Therapeutic Jurisprudence-An Israeli Perspective, 33 T. JEFFERSON L. REV. 351 (2008). 
These skills include the ability to convey empathy and respect, communicate effectively with the individual, listen to what the individual has to say (thereby fulfilling the individual's need for voice and validation), earn the individual's trust and confidence, and engage in motivational interviewing and various other techniques designed to encourage the individual to accept treatment and comply with it. ${ }^{65}$ Judges in such courts must have the capacity to "break free from the statutory shackles that "transformed them into mid-level bureaucrats." far more likely that these judges will be culturally competent and thus able to "unpack" the testimony of persons subject to civil commitment who do not come from the mainstream culture. ${ }^{67}$ These courts provide "nuanced" approaches ${ }^{68}$ and may signal a "fundamental shift" in the criminal justice system. ${ }^{69}$ According to former Judge Randal Fritzler, a successful mental health court thus needs: (1) a therapeutic environment and dedicated team; (2) an environment free from stigmatizing labels; (3) opportunities for deferred sentences and diversion away from the criminal system; (4) the least restrictive alternatives; (5) decision-making that is interdependent; (6) coordinated treatment, and (7) a review process that is meaningful. ${ }^{70}$ It

65. For a thoughtful critique of MHCs, see Johnston, supra note 55. On the role of the legislature in insuring the success of such courts, see Sheila Moheb, Jamming the Revolving Door: Legislative Setbacks for Mental Health Court Systems in Virginia, 14 Rich. J.L. \& PUB. INT. 29, 38-41 (2010).

66. Castellano, supra note 43, at 399 (quoting, in part, Richard Boldt \& Jana Singer, Juristocracy in the Trenches: Problem-Solving Judges and Therapeutic Jurisprudence in Drug Treatment Courts and Unified Family Courts, 65 MD. L. REV. 82, 84 (2006)).

67. See Perlin \& Weinstein, supra note 40, at 100 (“Cultural competence is a key component in providing effective representation and resolving any ethical dilemmas that may arise in elder law, just as it is in mental disability law."); see also, e.g., Ruby Dhand, Creating a Cultural Analysis Tool for the Implementation of Ontario 's Civil Mental Health Laws, 45 INT'L J.L. \& PSYCHIATRY 25, 32 (2016) (recommending further that cultural and other intersectional factors be probed during the civil commitment hearing processes). See generally Michael L. Perlin \& Valerie R. McClain, "Where Souls Are Forgotten": Cultural Competencies, Forensic Evaluations and International Human Rights, 15 Psychol. PuB. Pol'Y \& L. 257 (2009); Casey Schutte, Mandating Cultural Competence Training for Dependency Attorneys, 52 FAM. CT. REV. 564 (2014).

For a discussion on how the public psychiatric system disproportionately marginalizes persons who are racial minorities, see Michael L. Perlin \& Heather Ellis Cucolo, "Tolling for the Aching Ones Whose Wounds Cannot Be Nursed": The Marginalization of Racial Minorities and Women in Institutional Mental Disability Law, 20 J. GENDER RACE \& JUST. 431 (2017).

68. Patricia C. McManus, A Therapeutic Jurisprudential Approach to Guardianship of Persons with Mild Cognitive Impairment, 36 SETON HALL L. Rev. 591, 598 (2006).

69. Harvard Law Review Ass'n, Mental Health Courts and the Trend Toward a Rehabilitative Justice System, 121 HARV. L. REV. 1168, 1176-77 (2008).

70. Randal B. Fritzler, 10 Key Components of a Criminal Mental Health Court, reprinted in Judging in a Therapeutic Key: TheraPeutic JuRisPrudenCE AND the COURTS 118, 118-21 (Bruce J. Winick \& David B. Wexler eds., 2003); Randal Fritzler, How One Misdemeanor Mental Health Court Incorporates Therapeutic Jurisprudence, Preventive Law, and Restorative Justice, in management and administration of Correctional Health Care: Policy, Practice, ADMINISTRATION 14-1, at 14-18 (Jacqueline Moore ed., 2003) ("The [mental health court] must avoid contributing negative stigma to its clients."); see also Georgia Lee Sims, The Criminalization of 
is essential that such courts be free of the "pretextual dishonesty" that is so often the hallmark of judicial proceedings in cases of individuals with mental disabilities. ${ }^{72}$

Because MHCs can divert persons with mental disabilities out of the criminal justice system (where they are likely to be treated as third- or fourth-class citizens, if those terms have any meaningful content or context), ${ }^{73}$ MHCs make it less likely that the person with mental disabilities will suffer at the hands of others because of that status. ${ }^{74}$ By way of example, Sana Loue concludes that sanist biases may be reduced by the establishment of MHCs, staffed by a "sensitive" judiciary. ${ }^{75}$ A study of Judge Ginger Lerner-Wren's MHC in Broward County concluded that participants in that court self-reported coercion levels lower than almost any comparable measure of perceived coercion previously reported in the literature. ${ }^{76}$ The actual, real-life experiences of the litigants in cases before

Mental Illness: How Theoretical Failures Create Real Problems in the Criminal Justice System, 62 VAND. L. REV. 1053, 1079 (2009).

71. I define "pretextuality" as the ways in which courts accept (either implicitly or explicitly) testimonial dishonesty and engage similarly in dishonest (and frequently meretricious) decisionmaking. See, e.g., Michael L. Perlin, "Simplify You, Classify You": Stigma, Stereotypes and Civil Rights in Disability Classification Systems, 25 GA. ST. U. L. REV. 607, 621 (2009).

72. See Ian Freckelton, Ideological Divarication in Civil Commitment Decision-Making, 10 PSYCHIATRY PSYCHOL. \& L. 390, 395 (2003); Ian Freckelton, Mental Health Review Tribunal Decision-Making: A Therapeutic Jurisprudence Lens, 10 PsYChIATRY PSYCHOL. \& L. 44, 59 (2003) (citing Michael L. Perlin, The Hidden Prejudice: Mental Disability on Trial 59-60 (2000)); Michael L. Perlin, Preface to Involuntary Detention and Therapeutic Jurisprudence: International Perspectives on Civil Commitment, at xxxiii, xxxiii-xxxvi (Kate Diesfeld \& Ian Freckelton eds., 2003).

73. For an analysis of court diversion from a critical disability studies perspective discussing how diversion programs in New South Wales ignore questions of social complexity in identifying those to be diverted, see Linda Steele, Leanne Dowse \& Julian Trofimova, Who Is Diverted? Moving Beyond Diagnosed Impairment Towards a Social and Political Analysis of Diversion, 38 SYDNEY L. REV. 179, 206 (2016).

74. Terry Carney et al., Mental Health Tribunals: “TJ" Implications of Weighing Fairness, Freedom, Protection and Treatment, 17 J. Jud. ADMIN. 46, 54 (2007); Risdon Slate, From the Jailhouse to Capitol Hill: Impacting Mental Health Court Legislation and Defining What Constitutes a Mental Health Court, 49 CRIME \& DeLINQ. 6, 6 (2003).

75. Sana Loue, The Involuntary Civil Commitment of Mentally Ill Persons in the United States and Romania, 23 J. LEGAL MED. 211, 235 n.120 (2002). On sanism in the context of MHCs, see Perlin, Gates of Eden, supra note 42, at 204-15, and Perlin, Cast His Robe, supra note 42, at 31-32. I define sanism as irrational prejudice of the same quality and character as other irrational prejudices that cause (and are reflected in) prevailing social attitudes of racism, sexism, homophobia, and ethnic bigotry that infects the entire legal process. Michael L. Perlin, On Sanism, 46 SMU L. ReV. 373, 374-75 (1992). It is also not unreasonable to suggest that a diminution of sanism might, as a side-benefit, bring additional, new lawyers to this area, willing to dedicate themselves to the representation of this population. See generally Michael L. Perlin \& Alison J. Lynch, How Teaching About Therapeutic Jurisprudence Can Be a Tool of Social Justice, and Lead Law Students to Personally and Socially Rewarding Careers: Sexuality and Disability as a Case Example, 16 NEv. L.J. 209, 216 (2015).

76. Norman G. Poythress et al., Perceived Coercion and Procedural Justice in the Broward Mental Health Court, 25 InT'L J.L. \& PSYCHIATRY 517, 529 (2002); see also David Tait, The Ritual 
Judge Lerner-Wren thus demonstrate that an MHC can be a non-coercive, dignified experience that provides procedural justice and therapeutic jurisprudence to those before it. ${ }^{77}$ In such courts, defendants participate more actively and directly than in typical criminal courts, often speaking directly with the judge instead of sitting silently while their defense attorney speaks for them. ${ }^{78}$ Treatment courts that provide the most time and attention from the presiding judge have been shown to be more successful. ${ }^{79}$ Professor Vicki Lens underscores the importance of a judge who "buys into" the principles of therapeutic jurisprudence (TJ): "[E]ven a well-resourced problem-solving court may not work if the judge fails to adopt TJ and other problem-solving strategies effectively."

Environment of the Mental Health Tribunal Hearing: Inquiries and Reflections, 10 PSYCHIATRY PSYCHOL. \& L. 91, 94-95 (2003). Successful judges in MHCs will typically demonstrate a sort of “charismatic authority," seen by Professor Castellano as "an essential element of judges' ability to achieve the complex tasks of building trust and managing risk among chronic reoffenders." Castellano, supra note 43, at 402; see also Fisler, supra note 55 (discussing the backgrounds of the first problemsolving court judges in New York). See generally Talesh, supra note 59. Looking specifically at the database that has developed around Judge Lerner-Wren's court, I have sought to rebut the argument that mental health court judges are "too dependent on the aura of the charismatic judge" in Perlin, Cast Your Robe, supra note 42, at 20.

77. See Judith Kaye, Lecture, 81 ST. JoHN's L. REV. 743, 748 (2007) (describing MHCs as follows: "mental health courts, which . . . divert defendants from jail to treatment, reconnect them, where possible, with family and friends who care whether they live or die, ... [and] restore their greatest loss - their sense of human dignity"). The author was the former Chief Judge of the New York Court of Appeals.

78. See Ginger Lerner-Wren, Broward's Mental Health Court: An Innovative Approach to the Mentally Disabled in the Criminal Justice System, in FUTURE TRENDS IN STATE COURTS 1999-2000 (2000), http://cdm16501.contentdm.oclc.org/cdm/ref/collection/spcts/id/184; see also Boothroyd et al., supra note 56, at 57; Castellano, supra note 43, at 401 ("[A] hallmark feature of problem solving courts is that judges speak directly to offenders with empathy and enthusiasm.").

On how judges in these courts "believe communicating directly to participants makes a difference in their lives," see Castellano, supra note 43, at 402 (citing, inter alia, Myesa Knox Mahoney, Procedural Justice and the Judge-Probationer Relationship in a Co-Occurring Disorders Court, 37 INT'L J.L. \& PSYCHIATRY 260 (2014)). Of course, judges' work in these courts contrasts sharply with the sort of "assembly-line justice" that they were pressured to administer when they worked in traditional courts. Castellano, supra note 43, at 401. Although the Supreme Court has disapproved of such "assembly-line justice," see Argersinger v. Hamlin, 407 U.S. 25, 36, 58 (1972); it is still often a reality. See generally CAROL WARREn, THE COURT OF LAST RESORT: MENTAL ILlneSS AND THE LAW 191 (1984); Candace McCoy, The Politics of Problem-Solving: An Overview of the Origins and Developments of Therapeutic Courts, 40 AM. CRIM. L. REV. 1513 (2003).

79. Emily Buss, Developmental Jurisprudence, 88 TEMP. L. REV. 741, 750 (2016) (citing Shelli B. Rossman \& Janine M. Zweig, What Have We Learned from the Multi-Site Adult Drug Court Evaluation? Implications for Policy, Practice, and Future Research, in 4 THE MulTI-SiTE ADULT Drug Court Evaluation: The IMPACT OF Drug Courts 251, 259-60 (Shelli B. Rossman et al. eds., 2013), http://www.courtinnovation.org/sites/default/files/documents/MADCE_4.pdf [https:// perma.cc/5ZP2-T3ST]; Peggy Fulton Hora \& Theodore Stalcup, Drug Treatment Courts in the Twenty-First Century: The Evolution of the Revolution in Problem-Solving Courts, 42 GA. L. REV. 717, 763-64 (2008).

80. Vicki Lens, Against the Grain: Therapeutic Judging in a Traditional Family Court, 41 LAW \& SOC. INQUIRY 701, 704 (2016). Beyond the scope of this paper is an evaluation of the potential role 
Professor Ursula Castellano has thoughtfully and insightfully argued that for MHCs to be successful, the presiding judge need practice what she calls "the politics of benchcraft," embedded in the alternative courtroom." 82 Such judges "selectively apply, blend and transform" elements from the treatment and legal spheres to adjudicate cases therapeutically and to "generate more effective solutions." 83

In this context, it should be noted that studies of the MHCs referred to here conclude that such courts actually work as they are intended to. ${ }^{84}$ Participants in Judge Ginger Lerner-Wren's MHC had significantly lower arrest rates after enrollment in treatment programs than before enrollment and lower post-enrollment arrest rates than comparison groups; in fact, MHCs evaluated in a multi-site study 85 "were more successful at reducing recidivism - recidivism rates of $25 \%$ versus $10 \%-15 \%$ "- than were drug courts. ${ }^{86}$ And these statistics are constant when juvenile MHCs are

of independent expert witnesses. On the use of such experts in traditional civil commitment cases, see supra notes 32-36 and accompanying text. Although one analysis of MHCs touts as a court advantage the "elimination of dueling experts," see Andrew Wasicek, Mental Illness and Crime: Envisioning a Public Health Strategy and Reimagining Mental Health Courts, 48 CRIM. L. BULL. ART 6 (2012). And, in John Shepard Wiley, Jr., Taming Patent: Six Steps for Surviving Scary Patent Cases, 50 UCLA L. REV. 1413, 1426 (2003), one judge noted that in his court, at least, "[n]ot infrequently there can be a request for a second opinion[.]" However, there is virtually no research literature whatsoever on the use of independent experts in these courts. Professors Baker and Zawid note that "expert testimony is common in mental health courts," but from the context of their article, they appear to be referring to testimony by team members, not independent expert witnesses. See Gregory Baker \& Jennifer Zawid, The Birth of a Therapeutic Courts Externship Program: Hard Labor but Worth the Effort, 17 ST. THOMAS L. REV. 711, 739 (2005).

81. Castellano, supra note 43 , at 403 . She defines this, in part, as "learning to finesse elements of treatment and law into new professional practices." Id.

82. Id. at 417 .

83. Id. Professor Castellano, in her study of four separate MHCs, found that the judges she observed were "deeply involved in investigating problems, collecting personal client information, and actively consulting with treatment professionals and law enforcement offices." $I d$. at 405.

84. These findings are not universal. I do have some concerns about the operationalization of the courts in some jurisdictions. See E. Lea Johnston \& Conor Flynn, Mental Health Courts and Sentencing Disparities, 62 VILL. L. REV. 685, 693 (2017) (empirical study of MHCs in Erie County, PA, concluding that anticipated treatment court sentences - for all grades of offense - typically exceed county court sentences by more than a year).

85. Greg Goodale, Lisa Callahan \& Henry J. Steadman, What Can We Say About Mental Health Courts Today? 64 PsychiATRIC SERVICES 298, 299 (2013) (citing, inter alia, Henry J. Steadman et al., Effect of Mental Health Courts on Arrests and Jail Days: A Multisite Study, 68 ARCHIVES GeN. PSYCHIATRY 167, 167-72 (2011)).

86. Id. See PERLIN \& CUCOLO, supra note 3, § 1-2.2.3, at 1-32 to 1-33 n.194 (citing, inter alia, Leonora Kopelovich et al., Procedural Justice in Mental Health Courts: Judicial Practices, Participant Perceptions, and Outcomes Related to Mental Health Recovery, 36 INT'L J.L. \& PSYCHIATRY 113 (2013)) (noting that procedural justice is positively correlated with participants' attitudes toward their own recovery); Mark R. Munetz et al., Mental Health Court and Assisted Outpatient Treatment: Perceived Coercion, Procedural Justice, and Program Impact, 65 PSYCHIATRIC SERVICES 352 (2014) (noting that mental health court graduates perceived significantly 
studied. ${ }^{87}$ Research also suggests that mental health court participation increases access to and utilization of mental health care, ${ }^{88}$ reduces the use of crisis or high-intensity services, and reduces substance use. ${ }^{89}$ The most recent relevant study-authored by a sitting trial judge- has thus concluded that "[p]roblem-solving treatment courts are the best way to

less coercion and more procedural justice in court than did those involved in assisted outpatient treatment proceedings); Allison Redlich \& Woojae Han, Examining the Links Between Therapeutic Jurisprudence and Mental Health Court Completion, 38 LaW \& Hum. BeHav. 109, 109 (2014) (noting that increased levels of procedural justice and perceived voluntariness led to decreased rates of new arrests in mental health court populations)); see also PERLIN \& CUCOLO, supra note 3, § 4-3.3; Priscilla Ferrazzi \& Terry Krupa, Mental Health Rehabilitation in Therapeutic Jurisprudence: Theoretical Improvements, 46 INT'L J.L. \& PSYCHIATRY 42 (2016) (arguing that greater consideration of mental health rehabilitation will improve the theoretical validity of therapeutic jurisprudence in this context); Evan Lowder, Sarah Desmarais \& Daniel J. Baucom, Recidivism Following Mental Health Court Exit: Between and Within-Group Comparisons, 40 LAW \& HUM. BEHAV. 118, 118 (2016) (noting that MHCs are particularly effective for high-risk participants, and time spent in such courts has positive effects on recidivism).

On the role of perceived coercion in the mental health court process, see Boothroyd et al., supra note 56, at 68, and Poythress et al., supra note 76. But cf. Laura N. Honegger, Does the Evidence Support the Case for Mental Health Courts? A Review of the Literature, 39 LAW \& HuM. BEHAV. 478, 478 (2015) (noting that existing studies of MHCs suffer from methodological limitationsspecifically, a lack of experimental design, use of non-representative samples, and assessment over short timeframes); Evan M. Lowder, Candalyn B. Rade \& Sarah L. Desmarais, Effectiveness of Mental Health Courts in Reducing Recidivism: A Meta-Analysis, 69 Psychiatric SERVICES 15 (2017), https://www.ncbi.nlm.nih.gov/pubmed/28806894 [https://perma.cc/Q28H-L3R4] (finding that test results showed a small effect of MHC participation on recidivism relative to traditional criminal processing; yet, MHCs were most effective with respect to jail time and charge outcomes compared with arrest and conviction).

87. Donna M.L. Heretick \& Joseph A. Russell, The Impact of Juvenile Mental Health Court on Recidivism Among Youth, 3 J. JUV. JUST. 1 (2013) (finding preliminary evidence that post-release recidivism rates of youth in the court were significantly lower than those for a sample of other youth in the juvenile justice system diagnosed with mental disorders). For a careful analysis of the differences between juvenile MHCs and traditional juvenile "guilty plea" courts, see Voula Marinos $\&$ Devon Gregory, The Tale of a Youth Guilty Plea Court \& A Youth Mental Health Court in Ontario: How Different Are They in Practice?, 2 INT'L J. THERAPEUTIC JURIS. 25 (2016-2017) (Marinos, Tales of a Court), and Voula Marinos, Methodologies for the Study of TJ Processes or Procedural Justice Within the Operation of TJ-Related Courts: A Conversation (Oct. 15, 2016) (unpublished manuscript presented at the annual Therapeutic Jurisprudence Workshop at Osgoode Hall Law Sch., York University, Toronto, Ont., Can.) (PowerPoint slides on file with author).

88. See, e.g., Boothroyd et al., supra note 56, at 68; Andrea M. Odegaard, Therapeutic Jurisprudence: The Impact of Mental Health Courts on The Criminal Justice System, 83 N.D. L. ReV. 225, 231 (2007). See generally Woojae Han \& Allison Redlich, The Impact of Community Treatment on Recidivism Among Mental Health Court Participants, 67 PsyChIATRIC Services 384 (2016) (noting that data showed increases in the receipt of community treatment among MHC participants and decreases in recidivism).

89. Kellie Canada, John Halloran \& Clark M. Peters, The Emergence of Mental Health Courts in the United States: Intersecting Innovation Between Psychiatric Care and the Law, 5 MENTAL HEALTH L. \& POL'Y J. 31, 57 (2016) (citing Erin Comartin et al., Short and Long-term Outcomes of Mental Health Court Participants by Psychiatric Diagnosis, 66 PsyChiatric SERVICES 923, 926 (2015); Kelly Fraling, How Mental Health Courts Function: Outcomes and Observations, 33 INT'L J.L. \& PSYCHIATRY 207, 212 (2010)). 
supervise criminal defendants in the community who present with high needs and a high risk to re-offend absent intervention. ${ }^{90}$

\section{A. From the Perspective of Procedural Justice}

Consider both these court systems in the context of procedural justice. 91 "Procedural justice" asserts that "people's evaluations of the resolution of a dispute (including matters resolved by the judicial system) are influenced more by their perception of the fairness of the process employed than by their belief regarding whether the 'right' outcome was reached." $" 92$ The research is consistent: "[T]he principal factor shaping [the] reactions [of the general public] is whether law enforcement officials exercise authority in ways that are perceived to be fair." 93 And, the fairness of the process used to reach a given outcome is critical to perceptions of legitimacy. ${ }^{94}$ The question to be asked is this: does the criminal justice system treat defendants fairly and respectfully regardless of the substantive outcome reached $?^{95}$

90. Kerry Meyer, Hennepin County Criminal Mental Health Court: Experiences in a Large Metropolitan Mental Health Court, 42 MitcheLl HAMLine L. REV. 485, 521 (2016). On how MHCs in some states can vary radically from county to county, see Monte Staton \& Arthur Lurigio, Mental Health Courts in Illinois: Comparing and Contrasting Program Models, Sanction Applications, Information Sharing, and Professional Roles, FED. PROB., June 2015, at 21. Of course, given the direct link with the criminal justice system, the potential power for coercion is certainly, at the least, a dormant issue. See, e.g., Stacey M. Faraci, Slip Slidin' Away? Will Our Nation's Mental Health Court Experiment Diminish the Rights of the Mentally Ill?, 22 QUINNIPIAC L. REV. 811, 853 (2004) (arguing that mental health court defendants "endure much more liberty restrictions and privacy intrusions" and that labeling the "sentence 'treatment,' rather than 'punishment," allows the court to exert more coercion over the participant than would otherwise be available). See generally Johnston \& Flynn, supra note 84 (reporting on negative mental health court data from one Pennsylvania county). I believe that when courts are modeled after the examples set by Judge Lerner-Wren, Judge D'Emic, and Judge Finkle, this will not happen. See Lerner-Wren, supra note 78, at 114-15.

91. The following section is generally adapted from PERLIN, A PRESCRIPTION FOR DigNiTy, supra note 50, ch. 6 .

92. Hafemeister, Garner \& Bath, supra note 50, at 200 (referencing, in part, Tom R. Tyler, Procedural Justice and the Courts, 44 CT. REV. 26, 26 (2007)); see also Larry Heuer, What's Just About the Criminal Justice System? A Psychological Perspective, 13 J.L. \& POL'Y 209, 213 (2005) (" $[\mathrm{P}]$ rocedural fairness concerns, rather than outcomes, are the best predictors of people's trust and confidence in the courts.").

93. Stephen J. Schulhofer, Tom R. Tyler \& Aziz Z. Huq, American Policing at a Crossroads: Unsustainable Policies and the Procedural Justice Alternative, 101 J. CRIM. L. \& CRIMINOLOGY 335, 346 (2011) (citing, inter alia, TOM R. TYLER \& Yuen J. HuO, TRUST IN THE LAW: ENCOURAGING Cooperation With the Police and the LaW (2002); Kimberly Belvedere, John L. Worrall \& Stephen G. Tibbetts, Explaining Suspect Resistance in Police-Citizen Encounters, 30 CRIM. JUST. REV. 30 (2005); Ben Bradford, Jonathan Jackson \& Elizabeth A. Stanko, Contact and Confidence: Revisiting the Impact of Public Encounters with the Police, 19 POLICING AND SOC'Y 20 (2009)).

94. David Welsh, Procedural Justice Post-9/11: The Effects of Procedurally Unfair Treatment of Detainees on Perceptions of Global Legitimacy, 9 U. N.H. L. REV. 261, 274 (2011).

95. Erin A. Conway, Ineffective Assistance of Counsel: How Illinois Has Used the "Prejudice" Prong of Strickland to Lower the Floor on Performance When Defendants Plead Guilty, 105 Nw. U. L. REV. 1707, 1732 (2011). The same insights apply in non-criminal cases as well. See generally 
When those affected by decision-making processes perceive the process to be just, "they are much more likely to accept the outcomes of the process, even when the outcomes are adverse." 96 Professor Tom Tyler's groundbreaking research has taught us that individuals with mental disabilities, like all other citizens, are affected by such process values as participation, dignity, and trust, and that experiencing arbitrariness in procedure leads to "social malaise and decreases people's willingness to be integrated into the polity, accepting its authorities and following its rules." 97

"There is a growing body of research showing that the experience of procedural justice not only enhances evaluations of persons, institutions, and specific outcomes, but also leads to greater overall satisfaction with the legal experience and more positive affect with respect to an encounter with the justice system." ${ }^{98}$ Perceptions of systemic fairness are driven, in large part, by "the degree to which people judge that they are treated with dignity and respect." 99 And, "[t]he public's perception of procedural

Rebecca Hollander-Blumoff, The Psychology of Procedural Justice in the Federal Courts, 63 HASTINGS L.J. 127, 133-34 (2011) (footnotes omitted).

Procedural justice research has shown that procedural justice effects are present in a wide range of settings. Civil litigants in court care about their treatment by a judge, criminal defendants care about their treatment by judge and jury, disputing parties in arbitration and mediation care about their treatment by an arbitrator or mediator, and even disputing parties in negotiation care about their treatment by the other party. Research outside the legal dispute resolution system has demonstrated that people care about their treatment by other authority figures, such as police officers, work supervisors, and health-care administrators. Beyond both the legal dispute-resolution context and the third party context, research has suggested that individuals care about procedural justice in highly relational settings like the family and even in classic economic settings like markets. Effects are found in field studies, simulations and experimental settings, and in situations with both low and very high stakes.

Hollander-Blumoff, supra note 95, at 133-34.

96. Hafemeister, Garner \& Bath, supra note 50, at 200 (quoting, in part, Michael M. O'Hear, Explaining Sentences, 36 FLA. ST. U. L. REV. 459, 478 (2009)). This applies as well to psychiatric hospital decision-making. See Bruce J. Winick, A Therapeutic Jurisprudence Approach to Dealing with Coercion in the Mental Health System, 15 PSYCHIATRY PsYCHOL. \& L. 25, 39 (2008) (discussing the importance of the "degree of respect" shown to patients by treatment providers).

97. Tom Tyler, The Psychological Consequences of Judicial Procedures: Implications for Civil Commitment Hearings, 46 SMU L. REV. 433, 443 (1992) (as discussed in Perlin \& Dorfman, supra note 21, at 119); see also Vidis Donnelly et al., Working Alliances, Interpersonal Trust and Perceived Coercion in Mental Health Review Hearings, 5 InT'L J. MENTAL HeAlth 29, 29 (2011) (noting that hearings perceived as lacking in procedural justice worsened working alliances between patients and physicians and diminished interpersonal trust) (cases heard in Ireland); Bruce J. Winick, Therapeutic Jurisprudence and the Civil Commitment Hearing, 10 J. CONTEMP. LEGAL IsSUES 37, 44 (1999) (noting that increasing a patient's "sense of participation, dignity, and trust" during a civil commitment proceeding will "increase his or her acceptance of the outcome of the hearing").

98. E. Allan Lind \& Tom R. Tyler, The Social Psychology of Procedural Justice 70 (1988).

99. Perlin, supra note 9, at 415 (quoting Tyler, supra note 96, at 442). See generally P. Christopher Earley \& E. Allan Lind, Procedural Justice and Participation in Task Selection: The Role 
justice - whether the criminal justice system treats defendants fairly and respectfully regardless of the substantive outcome reached-determines the public's willingness to engage in and comply with the system."100

The procedural justice differences between traditional civil commitment courts—-dark, "greased runways" with disinterested judges and lawyers ${ }^{101}$ - and modern MHCs - dignity-enforcing and coercionavoiding - could not be starker. ${ }^{102}$ In a thoughtful article about the role of procedural justice in the civil commitment process, Brian McKenna and his colleagues note "the clinical and ethical importance of procedural justice principles in the enactment of civil commitment," stressing that "these principles involve allowing patients to have their say, listening to them seriously, providing patients with information and treating them with concern, fairness and respect." ${ }^{\text {"103 }}$ The late Professor Bruce Winick has observed that "[p]erhaps nothing can threaten a person's belief that he or she is an equal member of society as much as being subjected to a civil commitment hearing" and, in this context, when "legal proceedings do not treat people with dignity, they feel devalued as members of society." 104

of Control in Mediating Justice Judgments, 52 J. PERSONALITY \& SOC. Psychol. 1148 (1987); Emily Gottfried, Joyce Carbonell \& Lauren Miller, The Impact of Judge-Defendant Communication on Mental Health Court Outcomes, 37 INT'L J.L. \& PSYCHIATRY 253 (2014) (“Mental health courts generally operate under the principle of treating defendants with mental disorders with respect and dignity, something that is perhaps missing from traditional court proceedings."); Norman G. Poythress, Procedural Preferences, Perceptions of Fairness, and Compliance with Outcomes, 18 LAW \& HUM. BEHAV. 361 (1994).

100. Conway, supra note 95, at 1732 (citing LIND \& TYLER, supra note 98, at 76-81).

101. On how the lawyers who represent patients in such courts often exhibit the worst of sanism, see generally Perlin, Could Be Your Funeral, supra note 10; Perlin, supra note 17. Although, state laws promise dignity in such proceedings. See, e.g., Colo. REV. STAT. ANN. § 27-65-101 (West 2016) as discussed in People v. In Interest of Vivekanathan, 338 P.3d 1017, 1025 (Colo. Ct. App. 2013) (civil commitment procedures must "provide the fullest possible measure of privacy, dignity, and other rights to persons undergoing care and treatment for mental illness"), this promise is often not met..

102. See Michael L. Perlin, Therapeutic Jurisprudence in Action, INT'L SOC'Y FOR THERAPEUTIC JURIS. (Sept. 5, 2015), https://mainstreamtj.wordpress.com/2015/09/05/therapeuticjurisprudence-in-action/ [https://perma.cc/9H6Y-NMEX] (discussing my experiences observing topflight problem-solving courts in New Zealand and concluding that "I have never, in such a short period of time, had the honor to observe such examples of therapeutic jurisprudence in action"). I discuss this further in Perlin \& Lynch, Mr. Bad Example, supra note 5, at 314-15.

103. Brian G. McKenna, Alexander I.F. Simpson \& John H. Coverdale, What Is the Role of Procedural Justice in Civil Commitment? 34 AUSTL. \& N.Z. J. PSYCHIATRY 671, 675 (2000). Judges rarely listen to patients in traditional civil commitment courts. For a rare judicial exception, see Rennie v. Klein, 476 F. Supp. 1294, 1306 (D.N.J. 1979) (citing Theodore Van Putten \& R.A. May, Subjective Response as a Predictor of Outcome in Pharmacotherapy, 35 ARCHIVES GEN. PSYCHIATRY 477, 480 (1978) ("Schizophrenics have been asked every question except, 'How does the medication agree with you?' Their response is worth listening to.”), modified, 653 F.2d 836 (3d Cir. 1983), vacated \& remanded, 458 U.S. 1119 (1982).

104. Winick, supra note 96, at 44-45. Importantly, this observation of Winick's was relied on by the Montana Supreme Court in In re Mental Health of K.G.F., 29 P.3d 485, 495 (Mont. 2001), a commitment case that I have previously referred to as "the most important case ever litigated in this 
Nearly forty years ago, John Ensminger and Thomas Liguori wrote that the civil commitment process had great therapeutic potential, stressing that such hearings optimally give patients an opportunity to present and hear evidence in a meaningful court procedure. ${ }^{105}$ The traditional civil commitment court does not give patients the opportunities highlighted by McKenna and his colleagues, by Winick, and by Ensminger and Liguori; however, the well-functioning mental health court does. ${ }^{106}$

\section{B. $\quad$ From the Perspective of Therapeutic Jurisprudence}

Consider next both these court systems in the context of therapeutic jurisprudence. ${ }^{107}$ Therapeutic jurisprudence presents a model for assessing the impact of case law and legislation, recognizing that, as a therapeutic agent, the law can have therapeutic or anti-therapeutic consequences. "The ultimate aim of therapeutic jurisprudence is to determine whether legal rules, procedures, and lawyer roles can or should be reshaped to enhance their therapeutic potential while not subordinating due process principles." 108

In the context of this paper, consider the impact of therapeutic jurisprudence specifically in the context of (1) the extent to which "legal rules, procedures, and lawyer roles can or should be reshaped to enhance their therapeutic potential while not subordinating due process

area." Perlin, Could Be Your Funeral, supra note 10, at 246. Recently, however, this case - which had found that the "adequacy of counsel" standard established by the U.S. Supreme Court for criminal cases was inadequate for civil commitment cases — was partially overruled in Matter of J.S., 401 P.3d 197 (Mont. 2017), calling for adherence to the Strickland standard.

105. John J. Ensminger \& Thomas D. Liguori, The Therapeutic Significance of the Civil Commitment Hearing: An Unexplored Potential, 6 J. PSYCHIATRY \& L. 5 (1978), reprinted in Wexler, THERAPEUTIC AGENT, supra note 7, at 245, 251-58. I discuss these insights, inter alia, in Perlin, supra note 20, at 742. On how formal hearings may force individuals before the court to "face reality," see Jennifer Fischer, A Comparative Look at the Right to Refuse Treatment for Involuntarily Hospitalized Persons with a Mental Illness, 29 HASTINGS INT’L \& COMP. L. REV. 153, 159 (2006).

106. On the significance of dignity values in involuntary civil commitment hearings, see Deborah A. Dorfman, Effectively Implementing Title I of the Americans with Disabilities Act for Mentally Disabled Persons: A Therapeutic Jurisprudence Analysis, 8 J.L. \& HeAlTH 105, 121 (1994), and Tyler, supra note 97, at 444-45. On how it is more likely in a well-functioning juvenile mental health court that those before the court will be consulted about decisions made about them, see Marinos, Tales of a Court, supra note 87.

107. See generally PERLIN \& CUCOLO, supra note 3, § 2-6, 2-43 to 2-66; DAVID B. WEXLER \& Bruce J. Winick, LaW in a Therapeutic Key: ReCENT DeVelopments in Therapeutic Jurisprudence (1996); Wexler, Therapeutic AgENT, supra note 7; BruCE J. Winick, Civil Commitment: A Therapeutic Jurisprudence Model (2005); David B. Wexler, Two Decades of Therapeutic Jurisprudence, 24 TOURO L. REV. 17 (2008). Wexler first used the term in a paper he presented to the National Institute of Mental Health in 1987. See David B. Wexler, Putting Mental Health into Mental Health Law: Therapeutic Jurisprudence, 16 LAW \& HuM. BeHAV. 27, 27, 32-33 (1992).

108. Perlin, Cast His Robe, supra note 42 , at $7-8$ (footnotes omitted). 
principles,"109 (2) how the law "actually impacts people's lives," whether the court system supports an "ethic of care," 111 and (4) the extent to which the legal system abides by the "three Vs" articulated by Professor Amy Ronner: voice, validation, and voluntariness. ${ }^{112}$ It is important to note that in his analysis of these issues, Professor Winick considered both individuals' emotional life and psychological well-being. ${ }^{113}$

I am struck with an anomaly that is at the core of this paper: civil commitment courts are-virtually across the board - the antithesis of therapeutic jurisprudence, in stark contrast to the TJ-modeling MHCs of the sort presided over by Judge Wren (and others, e.g., Judge Matthew

109. Perlin \& Lynch, supra note 75, at 213; see also Michael L. Perlin \& Alison J. Lynch, "In the Wasteland of Your Mind": Criminology, Scientific Discoveries and the Criminal Process, 4 VA. J. CRIM. L. 304 (2016). The author has been considering these questions for over two decades. See Michael L. Perlin, What Is Therapeutic Jurisprudence? 10 N.Y.L. ScH. J. Hum. RTS. 623 (1993).

110. Bruce J. Winick, Foreword: Therapeutic Jurisprudence Perspectives on Dealing with Victims of Crime, 33 Nova L. REv. 535, 535 (2009). I discuss this insight, inter alia, in Perlin \& Lynch, supra note 109, at 349, and Michael L. Perlin, "Yonder Stands Your Orphan with His Gun": The International Human Rights and Therapeutic Jurisprudence Implications of Juvenile Punishment Schemes, 46 TEX. TECH L. REV. 301, 331 (2013).

111. Warren Brookbanks, Therapeutic Jurisprudence: Conceiving an Ethical Framework, 8 J.L. \& Med. 328, 334 (2001); see also David B. Wexler, Not Such a Party Pooper: An Attempt to Accommodate (Many of) Professor Quinn's Concerns About Therapeutic Jurisprudence Criminal Defense Lawyering, 48 B.C. L. REv. 597, 599 (2007).

112. Amy D. Ronner, The Learned-Helpless Lawyer: Clinical Legal Education and Therapeutic Jurisprudence as Antidotes to Bartleby Syndrome, 24 TOURO L. REV. 601, 627 (2008). According to Professor Ronner:

What "the three Vs" commend is pretty basic: litigants must have a sense of voice or a chance to tell their story to a decision maker. If that litigant feels that the tribunal has genuinely listened to, heard, and taken seriously the litigant's story, the litigant feels a sense of validation. When litigants emerge from a legal proceeding with a sense of voice and validation, they are more at peace with the outcome. Voice and validation create a sense of voluntary participation, one in which the litigant experiences the proceeding as less coercive. Specifically, the feeling on the part of litigants that they voluntarily partook in the very process that engendered the end result or the very judicial pronunciation that affects their own lives can initiate healing and bring about improved behavior in the future. In general, human beings prosper when they feel that they are making, or at least participating in, their own decisions.

Amy D. Ronner, Songs of Validation, Voice, and Voluntary Participation: Therapeutic Jurisprudence, Miranda and Juveniles, 71 U. CIN. L. REV. 89, 94-95 (2002) [hereinafter Ronner, Songs of Validation]. On how mental health court judges are expected "to practice law as a healing profession," see Castellano, supra note 43 , at 400 . On the law and healing in a mental disability context generally, see Perlin, supra note 9. I discuss Ronner's insights in this context in Perlin, Cast His Robe, supra note 42 , at $8-9$.

113. Winick, supra note 110, at 535; see also David B. Wexler \& Bruce J. Winick, Putting Therapeutic Jurisprudence to Work: The Term May Sound Academic, but It Embodies a Hands-On Approach to Solving Problems Rather than Simply Winning Cases, ABA. J., May 2003, at 54, 54. 
D'Emic in Brooklyn ${ }^{114}$ and Judge Michael Finkle in Seattle ${ }^{115}$ ). MHCswhen structured properly and when chaired by a judge who "buys into" the TJ model - are perfect exemplars of the practical utility of therapeutic jurisprudence. ${ }^{116}$ As one commentator has noted, therapeutic jurisprudence "has expanded the role of courts to include a rehabilitative process." 117

The promotion and creation of such courts are consistent with TJ's aims and aspirations, ${ }^{118}$ especially where litigants are given the "voice" that TJ demands. ${ }^{119}$ The courts are grounded ${ }^{120}$ and rooted $^{121}$ in $\mathrm{TJ}$; they reflect TJ "theory in practice;" ${ }^{22}$ and they acknowledge that a defendant's appearance in such a court comes at a "painful and crucial point in life." 123 But these TJ-friendly, TJ-inspiring, and TJ-enforcing courts - courts that, better than any others, provide an environment that is not stigmatizing and not sanist ${ }^{124}$ - have had no impact at all on the "greased runways" of the courts, where litigation is done in "pitch darkness." 125

114. See generally Matthew J. D'Emic, Mental Health Courts: Bridging Two Worlds, 31 Touro L. REv. 369 (2015) [hereinafter D'Emic, Bridging]; Matthew J. D'Emic, The Promise of Mental Health Courts, CrIM. Just., Fall 2007, at 24. For more on Judge D'Emic's court, see Mark Fass, Program Steers Mentally Ill Defendants Away from Jail and Toward Treatment, N.Y. L.J., Aug. 4, 2008.

115. See generally Anne Harper \& Michael J. Finkle, Mental Health Courts, Judicial Leadership and Effective Court Intervention, JUDGES' J., Spring 2012, at 4.

116. See generally Kate Diesfeld \& Brian McKenna, The Therapeutic Intent of the New Zealand Mental Health Review Tribunal, 13 PsychiatRY PsychoL. \& L. 100 (2006); Kate Diesfeld \& Brian McKenna, The Unintended Impact of the Therapeutic Intentions of the New Zealand Mental Health Review Tribunal? Therapeutic Jurisprudence Perspectives, 14 J.L. \& MED. 566 (2007); Jelena Popovic, Court Process and Therapeutic Jurisprudence: Have We Thrown the Baby Out with the Bathwater? 1 ELAW J. 60 (2006) (Austl.).

117. Andrea M. Odegaard, Therapeutic Jurisprudence: The Impact of Mental Health Courts on the Criminal Justice System, 83 N.D. L. REV. 225, 258 (2007).

118. See Leroy Kondo, Advocacy of the Establishment of Mental Health Specialty Courts in the Provision of Therapeutic Justice for Mentally Ill Offenders, 24 SEATTLE U. L. REV. 373, 446-47 (2000).

119. Nicola Ferencz \& James McGuire, Mental Health Review Tribunals in the UK: Applying a Therapeutic Jurisprudence Perspective, 37 CT. REV. 48, 51 (2000).

120. James L. Nolan, Jr., Redefining Criminal Courts: Problem-Solving and the Meaning of Justice, 40 AM. CRIM. L. REV. 1541, 1541 (2003).

121. John Cummings, The Cost of Crazy: How Therapeutic Jurisprudence and Mental Health Courts Lower Incarceration Costs, Reduce Recidivism, and Improve Public Safety, 56 LoY. L. REV. 279, 280-81 (2010); Wasicek, supra note 79, at 126.

122. Michael Codben \& Ron Albers, Beyond the Squabble: Putting the Tenderloin Community Justice Center in Context, 7 HASTINGS RACE \& POVERTY L.J. 53, 56 (2010).

123. D'Emic, Bridging, supra note 114, at 376.

124. See, e.g., Michael L. Perlin, "My Sense of Humanity Has Gone Down the Drain": Stereotypes, Stigma and Sanism, in SteREOTYPING AS A HuMAN Rights Issue 95 (Alexandra Timmer \& Eva Brehms eds., 2015).

125. I know of only one exception: in Maricopa County (Phoenix), Arizona, one unified court hears both traditional civil commitment cases and the sorts of criminal cases typically diverted to 
In a book and in a series of recent papers, I have focused on the need for dignity in the legal process in cases involving persons with mental disabilities. ${ }^{126}$ One of the central principles of $\mathrm{TJ}$ is a commitment to dignity. ${ }^{127}$ With my colleagues, Keri Gould and Deborah Dorfman, I have concluded that " $[\mathrm{t}]$ he perception of receiving a fair hearing is therapeutic because it contributes to the individual's sense of dignity and conveys that he or she is being taken seriously." ${ }^{28}$ In a recent article about dignity and the civil commitment process, Professors Jonathan Simon and Stephen Rosenbaum embrace therapeutic jurisprudence as a modality of analysis and focus specifically on this issue of voice: "When procedures give people an opportunity to exercise voice, their words are given respect, decisions are explained to them their views taken into account, and they substantively feel less coercion." 229 With my colleague Naomi Weinstein, I have recently argued that "attorneys must embrace the principles and tenets of therapeutic jurisprudence as a means of best ensuring the dignity of their clients and of maximizing the likelihood that voice, validation and

MHCs. Personal Communication with Michael Jones, Retired Judge, Maricopa City Superior Court (Oct. 17, 2016)

126. See, e.g., Perlin, supra note 50; Heather Ellis Cucolo \& Michael L. Perlin, Promoting Dignity and Preventing Shame and Humiliation by Improving the Quality and Education of Attorneys in Sexually Violent Predator (SVP) Civil Commitment Cases, 28 U. FLA. J.L. \& PUB. POL'y 291 (2017); Mehgan Gallagher \& Michael L. Perlin, "The Pain I Rise Above": How International Human Rights Can Best Realize the Needs of Persons with Trauma-Related Mental Disabilities, FLA. J. INT'L L. (forthcoming 2018); Michael L. Perlin, "Dignity Was the First to Leave”: Godinez v. Moran, Colin Ferguson, and the Trial of Mentally Disabled Criminal Defendants, 14 BEHAV. SCI. \& L. 61 (1996); Michael L. Perlin \& Naomi Weinstein, "Friend to the Martyr, a Friend to the Woman of Shame": Thinking About the Law, Shame and Humiliation, 24 S. CAL. REV. L. \& Soc. Just. 1 (2014); Michael L. Perlin, "God Said to Abraham/Kill Me a Son": Why the Insanity Defense and the Incompetency Status Are Compatible with and Required by the Convention on the Rights of Persons with Disabilities and Basic Principles of Therapeutic Jurisprudence, 54 AM. CRIM. L. Rev. 477 (2017); Perlin \& Lynch, supra note 109; Perlin, Gates of Eden, supra note 42; Perlin, Cast His Robe, supra note 42; Perlin \& Lynch, To Wander Off in Shame, supra note 44; Michael L. Perlin, Understanding the Intersection Between International Human Rights and Mental Disability Law: The Role of Dignity, in THe Routledge HANDBOOK OF InTERnATIONAL CRime AND Justice STUdies 191 (Bruce Arrigo \& Heather Bersot eds., 2013); Weinstein \& Perlin, Who's Pretending to Care for Him?, supra note 10.

127. See generally WINICK, supra note 107 , at 161 . Dignity inquiries permeate the criminal justice system, especially as the concept applies to persons with mental disabilities.

128. Perlin, Gould \& Dorfman, supra note 28, at 114 (emphasis added).

129. Jonathan Simon \& Stephen A. Rosenbaum, Dignifying Madness: Rethinking Commitment Law in an Age of Mass Incarceration, 70 U. MIAMI L. REV. 1, 51 (2015). 
voluntariness ${ }^{130}$ will be enhanced." ${ }^{\prime 131}$ I believe that rejecting the traditional civil commitment court model and embracing the modern mental health court model is the single-best way that this dignity can be provided. ${ }^{132}$

\section{CONCLUSION}

There are other issues to consider as well. Although a robust literature has developed about MHCs, and although researchers have begun to focus on a broad-range of empirical issues, such as the extent to which defendants are competent to waive their trial rights in such settings, the quality of counsel, the significance of diversion, etc., ${ }^{133}$ there is still virtually nothing in the legal literature on these precise questions in this context. ${ }^{134}$ Bruce Winick has sketched the outlines of what lawyers must

130. See Ronner, Songs of Validation, supra note 112. Ironically, and importantly, a "voluntary" status in mental health commitment is not always truly voluntary. On the ways that hospital staff can routinely manipulate such disparity in bargaining to coerce patients into accepting voluntary commitment status (thus avoiding court hearings), see Susan Reed \& Dan Lewis, The Negotiation of Voluntary Admission in Chicago's State Mental Hospitals, 18 J. PSYCHIATRY \& L. 137, 143-48 (1990); see also Joel Haycock et al., Mediating the Gap: Thinking About Alternatives to the Current Practice of Civil Commitment, 20 NEw ENG. J. ON CRIM. \& CIV. CONFINEMENT 265, 278 (1994) ("[The patient's lawyers], in collusion with the care-givers, disempower him or her and effectively thwart the establishment of a voluntary treatment compact between the patient and mental health professionals.").

131. Perlin \& Weinstein, supra note 40 , at 115.

132. See generally David Yamada, Dignity, "Rankism," and Hierarchy in the Workplace: Creating a "Dignitarian" Agenda for American Employment Law, 28 BERKELEY J. EMP. \& LAB. L. 305 (2007) (reviewing Robert W. Fuller, All Rise: Somebodies, Nobodies, AND the Politics

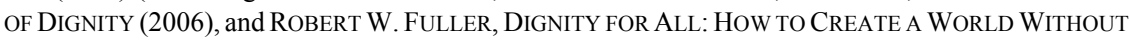
RANKISM (2008)). I am grateful to Professor Yamada for introducing me to the work of Professor Fuller.

133. Perlin, Cast His Robe, supra note 42, at 16-17 (discussing, among other things, Steven Erickson et al., Variations in Mental Health Courts: Challenges, Opportunities, and a Call for Caution, 42 Comm. Mental Health J. 335, 339 (2006); Faraci, supra note 90, at 828-29 (discussing competency of defendants to accept transfer to MHCs)); see also Terry Carney, The Mental Health Service Crisis of Neoliberalism - An Antipodean Perspective, 31 INT'L J.L. \& PSYCHIATRY 101, 111 (2008) (discussing competency of counsel assigned to defendants in MHCs); Erickson et al., supra note 133, at 340; Allison D. Redlich, Voluntary, but Knowing and Intelligent?, 11 PsYCHOL. PuB. POL'Y \& L. 605 (2005) (discussing competency of MHC defendants to fully comprehend court processes and requirements).

134. I believe the questions that I have raised about quality of counsel in the representation of criminal defendants with mental disabilities in the criminal justice system in PERLIN, supra note 19, must be considered in the context of MHCs, but I know of no scholarly research in the legal literature that has focused on these issues. See Michael L. Perlin, "Wisdom Is Thrown into Jail": Using Therapeutic Jurisprudence to Remediate the Criminalization of Persons with Mental Illness, 17 MicH. ST. U. J.L. \& MED. 343, 368-69 (2013) [hereinafter Perlin, Wisdom Is Thrown] (raising this issue); Michael L. Perlin, "To Show That ... the Courts Are on the Level": Addressing Questions of Competency and Adequacy of Counsel in Mental Health Courts (Nov. 2016) (unpublished manuscript presented to the American Society of Criminology, New Orleans, La.) (PowerPoint on file with author). 
do in the representation of clients in these courts, ${ }^{135}$ but little scholarly attention has been given to a range of important issues that affect the operation of these courts and the role of lawyers representing clients in them. ${ }^{136}$ Even a TJ-centric court will only be able to do so much if we do not take seriously questions as to the adequacy of counsel in this specific context. For it is fair process norms, such as the right to counsel, that "operate as substantive and procedural restraints on state power to ensure that the individual suspect is treated with dignity and respect." ${ }^{137}$ And if this right is ensured, then and only then will courts administering civil commitment proceedings live up to their potential.

The title of this paper draws on Bob Dylan's song, Ring Them Bells, ${ }^{138}$ and is found in the fourth line of this stanza:

Ring them bells for the blind and the deaf

Ring them bells for all of us who are left

Ring them bells for the chosen few

Who will judge the many when the game is through ${ }^{139}$

Here, Dylan sings of the bells ringing for others with disabilities ("the blind and the deaf") and those who are outsiders ("us who are left"). According to the preeminent Dylanologist Oliver Trager, the song "ach[es] with compassion," "140 and I think that is appropriate for use in this paper. Therapeutic jurisprudence "ach[es] with compassion." Traditional civil commitment courts make me ache with sadness. I am hoping that some of the TJ spirit that imbues successful MHCs will eventually be

135. For a valuable recommendation as to what attorneys should do in such circumstances, see Perlin, Wisdom Is Thrown, supra note 134, at 369-70 (quoting Stefan \& Winick, supra note 61, at 511, 517, 520). Professor Winick made the following comments: "Lawyers should adequately counsel their clients about the advantages and disadvantages of accepting diversion to mental health court ... . As a result, judges and defense counsel in mental health courts should ensure that defendants receive dignity and respect, [and] are given a sense of voice and validation." Id. at 516, 523.

136. On other important questions raised about the use of MHCs, see Canada, Halloran \& Peters, supra note 89, at 58-59 (discussing whether the low numbers of such courts means that they play "no more than a niche role" in the criminal justice/mental health system; whether admission into such courts "prioritize $[\mathrm{s}]$ and privilege $[\mathrm{s}]$ " some defendants over others; whether lack of additional resources will lead such courts into becoming "a dangerous extension of state authority"; whether court gatekeepers are rigorous in clearly identifying who should be included and who should be excluded from such courts; and whether justice and therapy are ultimately incompatible, a question that the authors readily concede "may be as unresolvable as it is unlikely to disappear").

137. Peter Arenella, Rethinking the Functions of Criminal Procedure: The Warren and Burger Courts' Competing Ideologies, 72 GEO. L.J. 185, 200 (1983).

138. Bob Dylan, RING THEM BELLS, OH MERCY (Columbia Records 1989), http://bobdylan.com/songs/ ring-them-bells/ [https://perma.cc/3QLC-JNA6].

139. Id.

140. Oliver Trager, Keys to the Rain: The Definitive Bob Dylan EnCyClopedia 521 (2004). 
shared with those traditional civil commitment courts to bring some light to the darkness that still envelops them. 